\title{
Hemochromatosis and Xeroderma Pigmentosum: Two (Un)Suspicious Neighbors
}

\author{
Filipa Monte $^{a}$ Mónica Garrido ${ }^{b}$ Tiago Pereira Guedes ${ }^{b}$ Joel Reis ${ }^{c}$ \\ Graça Porto $^{d, e}$ Isabel Pedroto ${ }^{a, b}$

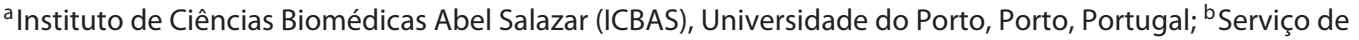 \\ Gastrenterologia, Centro Hospitalar Universitário do Porto (CHUP), Porto, Portugal; ' Serviço de Dermatologia, \\ Centro Hospitalar Universitário do Porto (CHUP), Porto, Portugal; ' ${ }^{d}$ Serviço de Hematologia, Centro Hospitalar \\ Universitário do Porto (CHUP), Porto, Portugal; ${ }^{e}$ Centro de Genética Preditiva e Preventiva, Instituto de Biologia \\ Molecular e Celular, Porto, Portugal
}

\section{Keywords}

Hereditary hemochromatosis $\cdot H F E \cdot$ Xeroderma

pigmentosum $\cdot \mathrm{POLH} \cdot$ Liver cirrhosis

\section{Abstract}

A 51-year-old woman, clinically diagnosed with Xeroderma pigmentosum (XP), showed abnormalities in liver enzymes, high ferritin and transferrin saturation levels, with ultrasonographic features of chronic liver disease, in addition to skin hyperpigmentation. Genetic testing confirmed the clinical hypothesis of hereditary hemochromatosis $(\mathrm{HH})$. Due to the known proximity of HFE (6p22.2) and POLH (6p21.1) genes, accountable for $\mathrm{HH}$ and the XP-V variant, respectively, a genetic test was offered and a rare variant of the POLH gene was identified. We report the first confirmed case, to our knowledge, of a patient diagnosed both with $\mathrm{XP}$ and $\mathrm{HH}$, in whom two mutated neighbor genes - POLH and HFE - were identified, possibly the result of genetic linkage.

C 2021 Sociedade Portuguesa de Gastrenterologia Published by S. Karger AG, Basel

Filipa Monte and Mónica Garrido shared co-first authorship.

\author{
Hemocromatose e Xeroderma Pigmentosum: dois \\ vizinhos (in)suspeitos
}

\section{Palavras Chave}

Hemocromatose Hereditária · HFE · Xeroderma

pigmentosum $\cdot \mathrm{POLH} \cdot$ Cirrose hepática

\section{Resumo}

Uma mulher de 51 anos, com antecedentes pessoais de Xeroderma pigmentosum (XP), apresentava, além de hiperpigmentação cutânea, alterações nas enzimas hepáticas, elevação da ferritina sérica e da saturação da transferrina, bem como alterações ecográficas compatíveis com doença hepática crónica. A realização de um teste genético permitiu confirmar a hipótese diagnóstica de Hemocromatose Hereditária $(\mathrm{HH})$. Pela proximidade conhecida dos genes HFE (6p22.2) e POLH (6p21.1), responsáveis pela $\mathrm{HH}$ e pelo XP-V, respetivamente, foi realizado um teste genético que detetou um polimorfismo raro do gene POLH. Reportamos o primeiro caso de uma paciente diagnosticada com XP e HH, na qual foram identificados dois genes vizinhos mutados - POLH e HFE -, possivelmente como resultado de ligação genética.

(c) 2021 Sociedade Portuguesa de Gastrenterologia Publicado por S. Karger AG, Basel

Mónica Garrido

Department of Gastroenterology

Centro Hospitalar Universitário do Porto (CHUP), Largo do Professor Abel Salazar PT-4099-001 Porto (Portugal)

monicasofiagarrido@gmail.com 


\section{Introduction}

Xeroderma pigmentosum (XP) is a rare autosomal recessive disorder of DNA repair with $100 \%$ penetrance and an estimated incidence in the United States and Western Europe of approximately 1 per 1,000,000 live births [1]. $\mathrm{XP}$ affects, mostly, sun-exposed skin and eyes due to an increased sensitivity to ultraviolet radiation (UVR). Mutations in any of the eight genes involved in the recognition and repair of UVR-induced DNA damage can be encountered, which ultimately lead to eight different subgroups: XPA through XPG, and XP-V. Both genders are equally affected. Compared to the general population, individuals with XP are at significantly higher risk of developing skin cancer, presenting at an earlier age. A clinical diagnosis is based on typical skin findings, including freckling before the age of two, xerosis, progressive atrophy and hyper/hypopigmentation. Severe solar erythema also occurs after minimal exposure to radiation, although this feature is not usually perceived in XPC, XPE and $\mathrm{XP}-\mathrm{V}$ subgroups, whose reaction to sun exposure is globally normal [2]. Ocular findings such as photophobia, xerophthalmia, conjunctival injection, ectropion and keratitis are also found [3], and, less commonly, neurodegenerative diseases, including sensorineural hearing loss, ataxia, areflexia, and peripheral neuropathy [4]. Along with clinical findings, a positive family history can support the diagnosis. Genetic testing confirms and categorizes the patient into one of the XP subgroups. In these patients, it is strictly recommended regular skin and eye examination, as well as avoiding sun exposure [5], to ensure an early management of premalignant and malignant skin lesions.

Hereditary hemochromatosis $(\mathrm{HH})$ is an autosomal recessive disorder, widely identified in Caucasians, in which, typically, biallelic inheritance of the p.C282Y variant in the HFE gene leads to inappropriately low levels of hepcidin which, by facilitating ferroportin mediated iron export, results in greater intestinal iron absorption with subsequent iron overload and tissue damage over time [6]. It takes about four decades in males and five to six decades in females to reach the iron threshold $(20 \mathrm{~g})$ associated with severe clinical manifestations [7]. Homozygosity for the p.C282Y variant (C282Y/C282Y) has an approximate prevalence of $1 / 150$ to $1 / 300$ in populations of northern European descent [8].

A genetic test with HFE genotyping is warranted in patients with hyperferritinemia and high transferrin saturation, confirmed in two determinations, after other frequent causes of hyperferritinemia have been excluded.

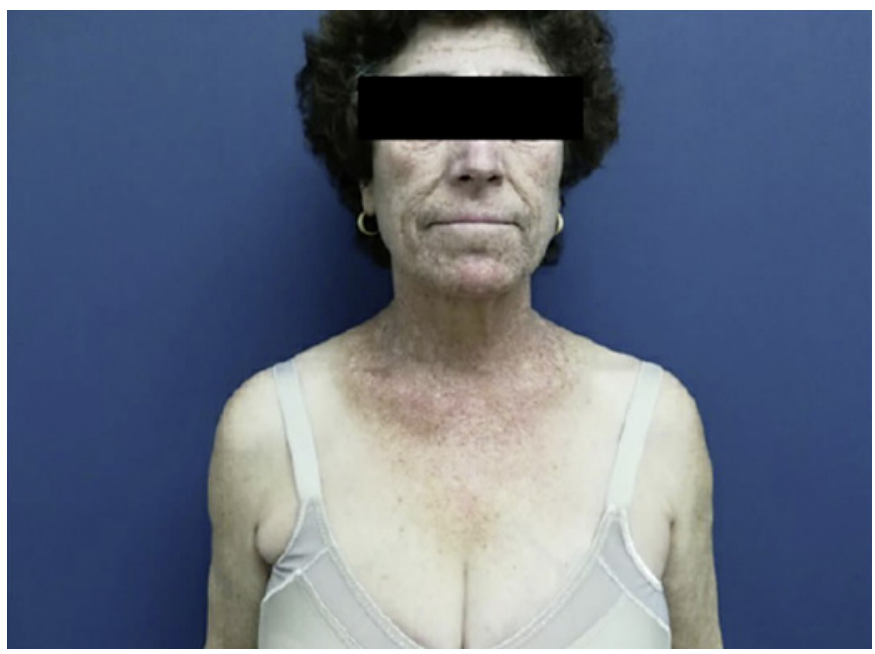

Fig. 1. Multiple solar lentigines and xerotic appearance in the photo-exposed area. Note the clear demarcation with the zone usually protected by clothes.

Phlebotomy is the treatment of choice to achieve ferritin targets between $50-100 \mu \mathrm{g} / \mathrm{L}$ and preventing the complications associated with tissue iron deposition. First-degree family members must be screened with ferritin, transferrin saturation and HFE genotype analysis [9].

We report a case of a 51-year-old woman, with a medical history of XP, who has been diagnosed with $\mathrm{HH}$. After genetic testing, it was possible to infer a possible linkage between two mutated neighbor genes (HFE and POLH).

\section{Case Report}

A 51-year-old Caucasian woman, with a history of skin hyperpigmentation, mainly in sun-exposed areas, since the age of 4 was clinically diagnosed with XP at 27 years. She has been previously submitted to complete excision of three basal cell carcinomas and two keratoacanthomas.

The patient was referred to our Hepatology Department, due to upper quadrant abdominal pain with evidence of liver enzymes abnormalities and an abdominal ultrasound showing loss of structural homogeneity, hypertrophy of the caudate lobe and mild splenomegaly, all suggestive of chronic liver disease. In addition to the $\mathrm{XP}$ diagnosis, the patient's medical history was notable for a history of menopause at the age of 40, essential arterial hypertension, osteoporosis, alcohol consumption of $12 \mathrm{~g}$ /day and no other risk factors for liver disease, namely, drugs or sexual risk behaviors. She was unaware of family history of hereditary diseases or consanguinity. Her physical examination was remarkable for a good general condition, a body mass index of $22.19 \mathrm{~kg} / \mathrm{m}^{2}$, a waist circumference of $89 \mathrm{~cm}$ and marked skin hyperpigmentation (Fig. 1). The 
Table 1. Initial analytical assessment

\begin{tabular}{|c|c|c|}
\hline & & $N$ \\
\hline Leukocytes & $3.13 \times 10^{3} / \mu \mathrm{L}$ & $(4-11)$ \\
\hline Hemoglobin & $15.4 \mathrm{~g} / \mathrm{dL}$ & $(12-15)$ \\
\hline Platelets & $89 \times 10^{3} / \mu \mathrm{L}$ & $(150-400)$ \\
\hline Glucose & $93 \mathrm{mg} / \mathrm{dL}$ & $(70-105)$ \\
\hline C-reactive protein & $1.40 \mathrm{mg} / \mathrm{L}$ & $(0-5)$ \\
\hline Creatinine & $0.56 \mathrm{mg} / \mathrm{dL}$ & $(0.5-0.9)$ \\
\hline Urea & $24 \mathrm{mg} / \mathrm{dL}$ & $(10-50)$ \\
\hline Sodium & $141 \mathrm{mmol} / \mathrm{L}$ & $(135-145)$ \\
\hline Potassium & $4.04 \mathrm{mmol} / \mathrm{L}$ & $(3.50-5.00)$ \\
\hline Albumin & $4.93 \mathrm{~g} / \mathrm{dL}$ & $(3.50-5.00)$ \\
\hline Total proteins & $7.53 \mathrm{~g} / \mathrm{dL}$ & $(6-7.3)$ \\
\hline Total bilirubin & $0.69 \mathrm{mg} / \mathrm{dL}$ & $(0.20-1.00)$ \\
\hline AST & $84 \mathrm{U} / \mathrm{L}$ & $(10-30)$ \\
\hline ALT & $75 \mathrm{U} / \mathrm{L}$ & $(10-36)$ \\
\hline ALP & $106 \mathrm{U} / \mathrm{L}$ & $(32-104)$ \\
\hline GGT & 286 & $(6-39)$ \\
\hline Alfa-fetoprotein & $4,5 \mu \mathrm{g} / \mathrm{L}$ & $(3.5-5.0)$ \\
\hline Total cholesterol & $145 \mathrm{mg} / \mathrm{dL}$ & $(0-200)$ \\
\hline High-density lipoprotein & $42 \mathrm{mg} / \mathrm{dL}$ & $(45-65)$ \\
\hline Triglycerides & $158 \mathrm{mg} / \mathrm{dL}$ & $(35-135)$ \\
\hline Serum iron & $247 \mu \mathrm{g} / \mathrm{dL}$ & $(50-100)$ \\
\hline Transferrin & $194 \mathrm{mg} / \mathrm{dL}$ & $(200-370)$ \\
\hline Transferrin saturation & $90 \%$ & $(15-45)$ \\
\hline
\end{tabular}

\begin{tabular}{|c|c|c|}
\hline & & $N$ \\
\hline Ferritin & $4,806 \mathrm{ng} / \mathrm{mL}$ & $(2,20-178)$ \\
\hline $\operatorname{IgA}$ & $244,0 \mathrm{mg} / \mathrm{dL}$ & $(114-457)$ \\
\hline IgG & $1,090.0 \mathrm{mg} / \mathrm{dL}$ & $(793-1590)$ \\
\hline $\operatorname{IgM}$ & $293.0 \mathrm{mg} / \mathrm{dL}$ & $(29-226)$ \\
\hline ANA & Negative & - \\
\hline AMA & Negative & - \\
\hline ASMA & Negative & - \\
\hline Anti-LKM & Negative & - \\
\hline Anti-LC1 & $0,4 \mathrm{U} / \mathrm{mL}$ & $(<18)$ \\
\hline Anti-SLA/LP & $0,1 \mathrm{U} / \mathrm{mL}$ & $(<18)$ \\
\hline CMV IgG & $70.3 \mathrm{AU} / \mathrm{mL}$ & $\begin{array}{l}\text { Positive }>11 \\
\text { Negative }<9\end{array}$ \\
\hline CMV IgM & 0.5 INDEX & $\begin{array}{l}\text { Positive }>1.2 \\
\text { Negative }<0.8\end{array}$ \\
\hline HBs Ag & Negative & \\
\hline Anti-HBs & Negative & \\
\hline Anti-HBc & Negative & \\
\hline Anti-HCV & Negative & \\
\hline Toxoplasma IgG & $0 \mathrm{UI} / \mathrm{mL}$ & $\begin{array}{l}\text { Positive }>30 \\
\text { Negative }<1\end{array}$ \\
\hline Toxoplasma IgM & 0.1 INDEX & $\begin{array}{l}\text { Positive }>1 \\
\text { Negative }<0.8\end{array}$ \\
\hline Fasciola hepatica & Negative & \\
\hline Echinococcus IgG & 3.3 INDEX & $\begin{array}{l}\text { Positive }>11 \\
\text { Negative }<9\end{array}$ \\
\hline
\end{tabular}

initial blood testing found abnormalities on liver enzymes (AST 84 U/L; ALT 75 U/L; ALP 106 U/L; GGT 286 U/L), thrombocytopenia (platelets $89 \times 10^{3} / \mu \mathrm{L}$ ), elevated transferrin saturation $(90 \%)$ and ferritin levels $(4,806 \mathrm{ng} / \mathrm{mL})$ (Table 1). An esophagogastroduodenoscopy was performed, showing no signs of portal hypertension.

Due to the substantial increase in ferritin and transferrin saturation levels, $\mathrm{HH}$ diagnosis was considered and later confirmed after HFE genotyping revealed C282Y homozygosity.

Additionally, magnetic resonance imaging was requested (Fig. 2), which showed a severe iron overload and estimated hepatic iron concentration of 300 micromoles per gram of dry weight (normal <36). Liver biopsy documented complete architectural disorganization and presence of regenerative nodules, confirming the diagnosis of liver cirrhosis, abundant hemosiderosis and severe steatosis (Fig. 3).

Dietary care was explained, focusing on alcohol cessation, and weekly therapeutic phlebotomies were started. Soon after, the patient developed large volume ascites, managed successfully with hyposaline diet and diuretics, without recurrence. Target values of ferritin were reached in 68 weeks, as well as normalization of serum transaminases, corresponding to an estimated amount of $7.9 \mathrm{~g}$ of iron removed. The patient started maintenance therapy with phlebotomies every 2 months thereafter. Additionally, she was administered with the Hepatitis B and pneumococcal vaccines and recommended the Influenza vaccine annually. Family screening was carried out and C282Y homozygosity was detected in two siblings and one grandson.

After a 10-year follow-up, the patient remains asymptomatic, with unremarkable blood tests. Liver ultrasound shows only evidence of diffuse steatosis. During this time interval, she was diagnosed with actinic keratosis on the right ala of the nose and on the 

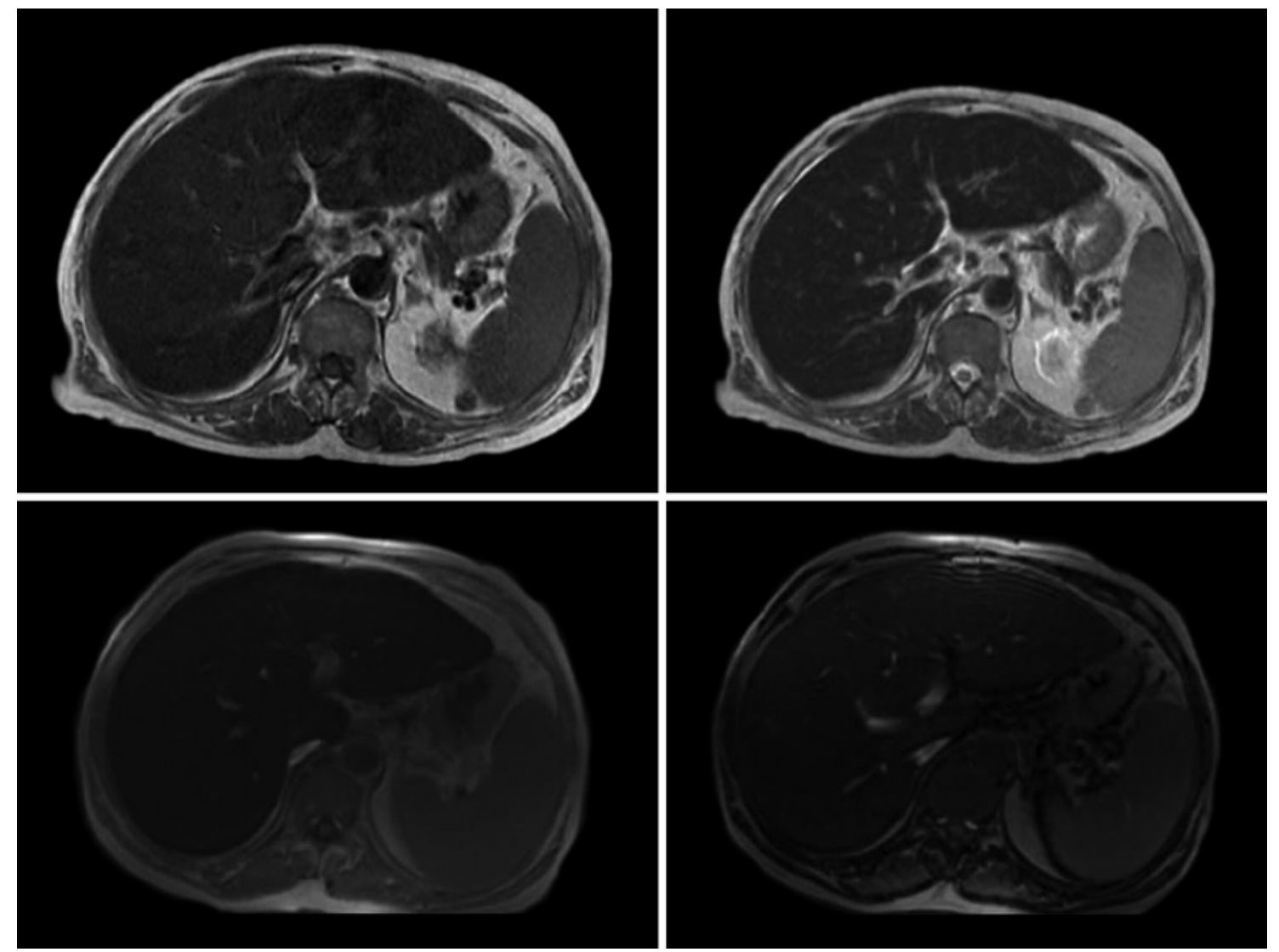

Fig. 2. MRI documenting in axial T1-weighted (upper left) and T2-weighted (upper right) images a decrease in the liver signal intensity. Axial T1-weighted gradient echo sequence images (lower panel) show a decreased signal intensity in the liver on the in-phase image (left) compared with the out-of-phase image (right), corroborating hepatic iron overload.
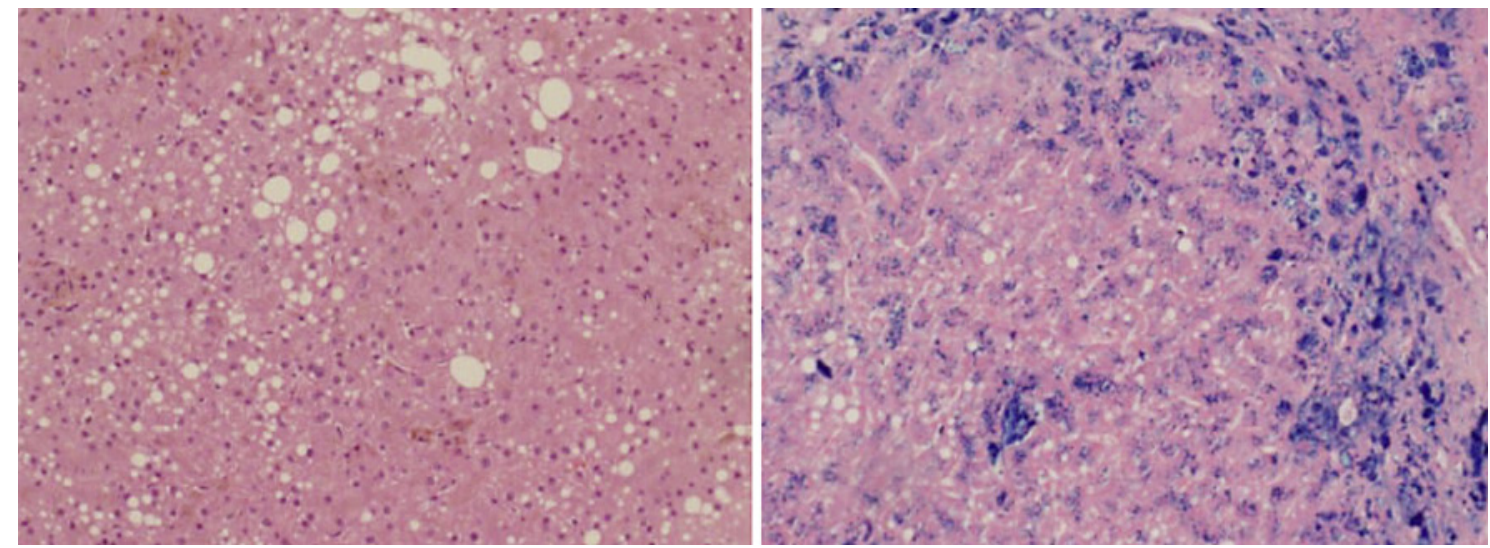

Fig. 3. Fragment of liver biopsy with hematoxylin-eosin staining $(100 \times)$, in which iron pigment stains brown (on the left); fragment of liver biopsy with Pearls staining (100×), in which the iron pigment stains blue (on the right). 
right forearm, managed with cryotherapy in the Dermatology Department. Due to the known proximity of $H F E$ (6p22.2) and $P O L H$ (6p21.1) genes, the patient was offered a genetic test to detect the latter mutation and was found to carry a rare, but potentially deleterious, homozygous variant of the $P O L H$ gene c.571A $>\mathrm{C}$ (p. (Thr191Pro)), of uncertain significance.

\section{Discussion/Conclusion}

This patient presented with laboratory and imaging evidence of chronic liver disease, including increased liver transaminases, GGT and ALP. The deposition of iron in hepatocytes does not cause inflammation per se [7] and most patients with hemochromatosis present transaminases within normal values. Given our patient history, it was not possible to exclude the role of alcohol consumption or metabolic syndrome as possible contributing factors for this elevation. In fact, excess alcohol intake is a major risk factor for the development of liver disease in patients with $\mathrm{HH}$ and iron overload potentiates the development of alcoholic liver disease [10]. Ferritin and transferrin saturation levels largely exceeded established cutoff values in our patient. Since ferritin is an acute-phase protein, it may also be increased in the context of systemic inflammatory processes, but usually at lower values and without increased hepatic iron storage [7].

Given that a definite diagnosis of $\mathrm{HH}$ can be made in the presence of p.C282Y homozygosity and increased iron stores, the patient was offered a genetic test, which confirmed HH. C282Y/C282Y has a $13.5 \%$ penetrance and is mainly associated with liver abnormalities, namely liver fibrosis and cirrhosis in 5 and $2 \%$ of women, respectively $[11,12]$. Although the diagnosis of menopause is clinical, determination of serum levels of FSH and estradiol can be useful to confirm the diagnosis in women aged 40-45 years [13]. In this woman, it would have been imperative to rule out the contribution of hypogonadotropic hypogonadism as a cause of secondary amenorrhea, which may have been misinterpreted, at first, as early menopause. Osteoporosis may be a direct consequence of hypoestrogenism, which leads to increased bone resorption.

Liver biopsy was the gold standard for the diagnosis of $\mathrm{HH}$ before HFE genotyping became widely available. Although it is not necessary for the diagnosis of $\mathrm{HH}$, it can be offered to C282Y homozygous individuals with ferritin levels $>1,000 \mathrm{ng} / \mathrm{mL}$, for the purpose of determining the presence or absence of advanced fibrosis or cirrhosis. Also, where there is hyperferritinemia with confounding cofactors, such as alcohol consumption or metabolic syndrome, like in our patient, liver biopsy may still be neces- sary to determine whether iron stores are increased or not $[9,14]$. The histological pattern favored the diagnosis of liver cirrhosis, with very severe hemosiderosis, supporting the clinical diagnosis of hemochromatosis.

Following the $\mathrm{HH}$ diagnosis, phlebotomies were initiated, reaching the target values of ferritin at the end of 68 weeks and normalization of serum transaminases. Since an improvement in biochemical parameters was achieved, as well as non-recurrence of ascites after ferritin targets were attained, we may assume that iron removal, along with cessation of alcohol consumption, contributed to the decrease in serum transaminases and eventually could represent a regression of liver fibrosis. Although regression of liver fibrosis is described to occur in about $15-50 \%$ of $\mathrm{HH}$ patients [15], it is not known if reversal occurs in established liver cirrhosis, which is widely accepted as a poor prognosis and worse survival factor [16].

Although this woman had not been genetically tested for XP before, the clinical findings were supportive of an $\mathrm{XP}-\mathrm{V}$ subgroup, since there was no abnormal skin reaction to sun exposure. This feature might have contributed to poor adherence to prophylactic measures, which led to hyperpigmentation and early malignant skin cancers. $\mathrm{XP}-\mathrm{V}$ has been found to be caused by $P O L H$ gene mutations, which prevent the production of any detectable DNA polymerase eta. A loss of this enzyme prevents cells from replicating UVR-damaged DNA effectively [17].

Due to the proximity of POLH and HFE genes, which can both be found in the short (p) arm of chromosome 6 at position 21.1 [17] and 22.2 [18], respectively, we suppose they could be linked, resulting in their inheritance as a unit, instead of assorting independently during meiosis. Therefore, the patient was offered a genetic test, which evidenced homozygosity for a rare sequence variant (c.571A $>C$ ) in the POLH gene. This mutation is of uncertain significance, so it does not confirm nor excludes the diagnosis of XP. However, considering the phenotype presented by our patient, this variant is most likely accountable for XP.

The most similar case was reported in 1932, concerning a 60 -year-old cirrhotic patient who had mottled pigmentation of the extremities and face. Although interpreted as hemochromatosis at first, a specimen from a pigmented macule on the hand revealed a typical histologic pattern of XP [19]. Despite the diagnosis of hemochromatosis was not put forward by the authors, we believe this case could correspond to the first association of both diseases.

This case highlights, overall, the importance of considering associated diseases when evaluating our patients.
Monte/Garrido/Pereira Guedes/Reis/ Porto/Pedroto 
Despite being rare, both diseases have effective, prognostic changing interventions, such as avoiding sun exposure and regular skin examination to prevent skin cancers, in $\mathrm{XP}$, and regular phlebotomies for $\mathrm{HH}$, to avoid deleterious tissue deposition of iron and prevent, among others, liver cirrhosis. Our patient presented skin hyperpigmentation, worsening over time, and initially attributed to the $\mathrm{XP}$, which led to a delay of $\mathrm{HH}$ diagnosis, already in a cirrhotic stage.

In conclusion, we report the first confirmed case, to our knowledge, of a patient diagnosed both with XP and $\mathrm{HH}$, in whom two mutated neighbor genes - POLH and $H F E$ - were identified. We believe this was not a random association but is possibly the result of genetic linkage. Since both conditions may present with overlapping clinical features, as skin hyperpigmentation, we pretend to alert clinicians to this possible association, since timely diagnosis of both XP and $\mathrm{HH}$ allows early guided interventions and improves patient outcomes.

\section{Acknowledgements}

We acknowledge João André Oliveira, MD, for MRI images and Rita Amorim, MD, for pathological images. We also acknowledge João Parente Freixo, MD, Rita Ferreira and Ana Filipa Brandão from CGPP/IBMC for the genetic testing.

\section{Statement of Ethics}

This study was approved by the Ethics Committee of Centro Hospitalar Universitário do Porto. The patient authorized and signed the consent form for image recording, submission and publication of this work.

\section{Conflict of Interest Statement}

This study has not been previously published and is not under consideration elsewhere. The authors have no conflicts of interest to declare.

\section{Funding Sources}

The authors did not receive support for this work in the form of grants, equipment, drugs, or any combination of theses.

\section{Author Contributions}

Drafting of the manuscript: F.M. and M.G. Critical revision of the manuscript and final approval of the version to be published: all listed authors.

\section{References}

1 Kleijer WJ, Laugel V, Berneburg M, Nardo T, Fawcett $\mathrm{H}$, Gratchev A, et al. Incidence of DNA repair deficiency disorders in western Europe: xeroderma pigmentosum, Cockayne syndrome and trichothiodystrophy. DNA Repair (Amst). 2008 May;7(5):744-50.

2 Sethi M, Lehmann AR, Fawcett H, Stefanini M, Jaspers N, Mullard K, et al. Patients with xeroderma pigmentosum complementation groups $\mathrm{C}, \mathrm{E}$ and $\mathrm{V}$ do not have abnormal sunburn reactions. Br J Dermatol. 2013 Dec; 169(6):1279-87.

3 Lim R, Sethi M, Morley AM. Ophthalmic Manifestations of Xeroderma Pigmentosum: A Perspective from the United Kingdom. Ophthalmology. 2017 Nov;124(11):1652-61.

4 Anttinen A, Koulu L, Nikoskelainen E, Portin R, Kurki T, Erkinjuntti M, et al. Neurological symptoms and natural course of xeroderma pigmentosum. Brain. 2008 Aug;131(Pt 8): 1979-89.

5 Hoesl M, Dietz K, Röcken M, Berneburg M. Vitamin D levels of XP-patients under stringent sun-protection. Eur J Dermatol. 2010 Jul-Aug;20(4):457-60.
6 Nemeth E, Tuttle MS, Powelson J, Vaughn MB, Donovan A, Ward DM, et al. Hepcidin regulates cellular iron efflux by binding to ferroportin and inducing its internalization. Science. 2004 Dec;306(5704):2090-3.

7 UpToDate [Internet]. Clinical manifestations and diagnosis of hereditary hemochromatosis [cited February 2, 2020]. Available from: https://www.uptodate.com/contents/clinical-manifestations-and-diagnosis-of-hereditary-hemochromatosis

8 Olynyk JK, Cullen DJ, Aquilia S, Rossi E, Summerville L, Powell LW. A populationbased study of the clinical expression of the hemochromatosis gene. N Engl J Med. 1999 Sep;341(10):718-24.

9 European Association For The Study Of The Liver. EASL clinical practice guidelines for HFE hemochromatosis. J Hepatol. 2010 Jul; 53(1):3-22.

10 Irving MG, Halliday JW, Powell LW. Association between alcoholism and increased hepatic iron stores. Alcohol Clin Exp Res. 1988 Feb; 12(1):7-13.
11 Bell H, Berg JP, Undlien DE, Distante S, Raknerud N, Heier HE, et al.; H. Bell, J. P. Berg, D. E. Undlien. The clinical expression of hemochromatosis in Oslo, Norway. Excessive oral iron intake may lead to secondary hemochromatosis even in HFE C282Y mutation negative subjects. Scand J Gastroenterol. 2000 Dec;35(12):1301-7.

12 Powell LW, Dixon JL, Ramm GA, Purdie DM, Lincoln DJ, Anderson GJ, et al. Screening for hemochromatosis in asymptomatic subjects with or without a family history. Arch Intern Med. 2006 Feb;166(3):294-301.

13 Stuenkel CA. Menopausal Hormone Therapy: current Considerations. Endocrinol Metab Clin North Am. 2015 Sep;44(3):56585.

14 Bacon BR, Adams PC, Kowdley KV, Powell LW, Tavill AS; American Association for the Study of Liver Diseases. Diagnosis and management of hemochromatosis: 2011 practice guideline by the American Association for the Study of Liver Diseases. Hepatology. 2011 Jul; 54(1):328-43. 
15 Milman N, Pedersen P, á Steig T, Byg KE, Graudal N, Fenger K. Clinically overt hereditary hemochromatosis in Denmark 19481985: epidemiology, factors of significance for long-term survival, and causes of death in 179 patients. Ann Hematol. 2001 Dec;80(12): 737-44.
16 Niederau C, Fischer R, Pürschel A, Stremmel W, Häussinger D, Strohmeyer G. Long-term survival in patients with hereditary hemochromatosis. Gastroenterology. 1996 Apr; 110(4):1107-19.

17 Genetics Home Reference [Internet]. POLH gene [cited April 7, 2020]. Available from: https://ghr.nlm.nih.gov/gene/POLH
18 Genetics Home Reference [Internet]. HFE gene [cited April 7, 2020]. Available from: https://ghr.nlm.nih.gov/gene/HFE

19 Montgomery H, Reuter M. Xeroderma pigmentosum: report of a mild case with histopathologic studies. Arch Derm Syphilol. 1932; 26(2):256-67. 